\title{
South-East Asian Fortified Stone Walls: Angkor Thom (Cambodia), Ho Citadel (Vietnam) and Ratu Boko (Indonesia)
}

\author{
Víctor Lluís Pérez Garcia \\ Universitat Rovira i Virgili \\ Email: victorlluisperez@yahoo.com
}

\begin{abstract}
This article aims to analyze three significant examples of defensive walls from SouthEast Asia made of solid stone blocks (both rock as well as stone-like laterite) and provided with different but equivalent functions -a fortified imperial capital-city (Angkor Thom, in Cambodia), a fortified royal citadel (Ho Citadel, in the North of Vietnam) and a royal palace with a partly fortified appearance (Ratu Boko, in Java Island, Indonesia)-, focusing on their constructive and technical characteristics and establishing parallels between them and their closest counterparts, from China and India. We will see how their design and structure can be closely related to the fortifications of neighbouring empires, as places of origin of their strong cultural influences and, at the same time, we will try to identify the local particularities. We will pay special attention to the form of the fortified enceintes, considering the long tradition of the quadrangular plan in the walls of royal capitals, inspired in the ideal model of Chinese and Indian cities. Our research also make us think that the walls of Ratu Boko, despite their functions as symbolic limits or for retaining the soil, could also have had a defensive purpose, no matter if secondary, or at least they could be used to provide protection to the complex in case of external menace.
\end{abstract}

Key words: archaeology, Asia, Cambodia, fortification, Indonesia, military architecture, Vietnam

\section{INTRODUCTION}

This article is the result of research conducted during a series of study visits to three important archaeological sites in Southeast Asia, focused on the analysis of stone walls -made from both rock as well as stone-like laterite- erected with a defensive function ${ }^{1}$. The most significant examples of the type in this geographical area undoubtedly can be located in Cambodia and Vietnam: Angkor Thom, in Siem Reap province (visited in 2009), and Ho Citadel, in Thanh Hóa province (personal collaboration with the local UNESCO staff in 2013). Furthermore, I also considered an outstanding case from Indonesia which served to establish interesting comparative links: Ratu Boko, in Yogyakarta (visited in 2014).

The two first monumental compounds were designated World Heritage sites by the United Nations Educational, Scientific and Cultural Organization (dates of inscription: 1992 and 2011, respectively), while the last one was included in a Tentative List (1995), due to their uniqueness and great historical-architectural value. In addition, each of them constitutes a different kind of civil structure provided with outer stone walls: a fortified imperial capital-city (Angkor Thom), a fortified royal citadel (Ho Citadel) and a royal palace with a partly fortified appearance (Ratu 
Boko). These were the main reasons for their choice as objects of study in my research.

Unlike the regions of East Asia $\left(\mathrm{China}^{2}, \mathrm{Japan}^{3}\right.$, Korea $^{4}$ ) and South Asia (India ${ }^{5}$ ), with abundant and ancient traditions of building stone fortifications (including city walls, military fortresses, castles and frontier long walls), Southeast Asia (mainland and insular) is very scarce in them. Also noticeable is the inexistence of specialized publications, neither strictly academic nor merely informative, devoted to the particular subject. Therefore, while examining attentively each one of these cases, I am going to focus on the constructive and technical characteristics of the stone perimetral walls and to try to establish parallels between them and their closest counterparts, from China and India.

\section{ANGKOR THOM (CAMBODIA)}

This is the most imposing stone fortification in the whole Southeast Asia, considering the monumental appearance of its gates, the uniqueness of its artistic decoration as well its remarkably long perimeter and overall huge size.

It is located in Siem Reap province, in the northwest of modern Cambodia, only about 20 $\mathrm{km}$ from Tonle Sap ("Great Lake"), the largest freshwater resource in the whole Indochinese Peninsula. The city was built on the west bank of the Siem Reap River, a tributary of Tonle Sap, in a plain terrain seasonally affected by floods, naturally surrounded by the tropical jungle.

The urban enceinte which can be visited nowadays belongs to the third capital city which was successively constructed in Angkor, all of them with vast regular quadrangular layouts and surrounded by wide moats filled with water. The first one, called Yasodharapura, was established by King Yasovarman I (889-910) and consisted of a square of $4 \mathrm{~km} \mathrm{x} 4 \mathrm{~km}$ (1600 ha) centred on the Phnom Bakheng temple. The second one, also with a square perimeter of $4 \mathrm{~km} \mathrm{x} 4 \mathrm{~km}$, was erected by King Udayadityavarman II (1050-1066) to the north and had the Baphuon temple in the middle. After the sack of Angkor by the Cham (1177), King Jayavarman VII (1181-1218), the most powerful Khmer monarch of all time, built a new capital for his empire, Angkor Thom, which kept this role until it was abandoned in $1432^{6}$; the magnificent temple of Bayon was placed in the centre, in the intersection of the two main roads, and the new city walls comprised part of the areas from the two previous capitals.

In its time Angkor Thom ${ }^{7}$ was the biggest city of Kambujadesa or Khmer Empire (802-1431), with an extension of 9 square kilometres (900 ha) and a remarkable population of nearly one million of inhabitants, including the citizens who lived inside and outside the walls ${ }^{8}$. Today it is probably the most important archaeological site of the whole Southeast Asia. Drawing an square of almost $3 \mathrm{~km}$ per side (3045 x $2927 \mathrm{~m})$, its defences consisted of a solid wall ${ }^{9}$ of almost 8 meters of height, bordered externally by a moat (100 metres wide and $6 \mathrm{~m}$ deep provided with drainage tunnels) and reinforced on the interior by an earthen rampart (15 $\mathrm{m}$ wide and 45 degrees of inclination) that forms a broad road around the interior of the perimeter. Both the wall and the embankment are pierced by small gutters for draining the water from the city towards the moats ${ }^{10}$.

Angkor Thom has five monumental tower-like gates or gopuras (23 m high), one in each side of the enceinte and a fifth one in the east corner ${ }^{11}$. With a cross-shaped plan, all of them have a single gateway (3'5 m wide, $7 \mathrm{~m}$ high and $16 \mathrm{~m}$ long) covered with a corbel or false vault, crowned with four distinctive gigantic stone faces representing the guardian bodhisattva Avalokitesvara which look towards the four cardinal directions, decorated with mythical three-headed elephants flanking the entrances, and preceded by an avenue of gods (devas), demons (asuras) and seven-headed monstrous serpents (nagas) lining the stone bridge (16 $\mathrm{m}$ long) across the moat.

The curtain walls were made mainly of hard rectangular laterite blocks laid in regular rows without joint mortar and buttressed by earth, with a parapet with carved corbel arches on the top and a decorative base in the bottom, both of them separated by mouldings. The type of laterite found in Angkor is limonite, rich in nickel. This reddish natural material was broadly used in South Asia, from India until the Indochinese Peninsula, throughout history. Although laterite is not technically a stone, it resembles a rock, given its aspect, composition and solidness ${ }^{12}$. That is the reason why I considered the analysis of the enceinte of Angkor Thom together with 
other main stone fortifications from South East Asia, discarding however those made of bricks. In addition to laterite, sandstone, a soft sedimentary rock obtained by Khmer builders from the Kulen mountains, was used as a secondary material due to its highest quality and cost in some important parts of the city wall that protected Angkor Thom, like the carved gates and the preceding causeways, as well as the corbel vault which crowns longitudinally the laterite walls.

Figure 1

Angkor Thom plan, Cambodia (AA.VV.: 1992, p. 54)

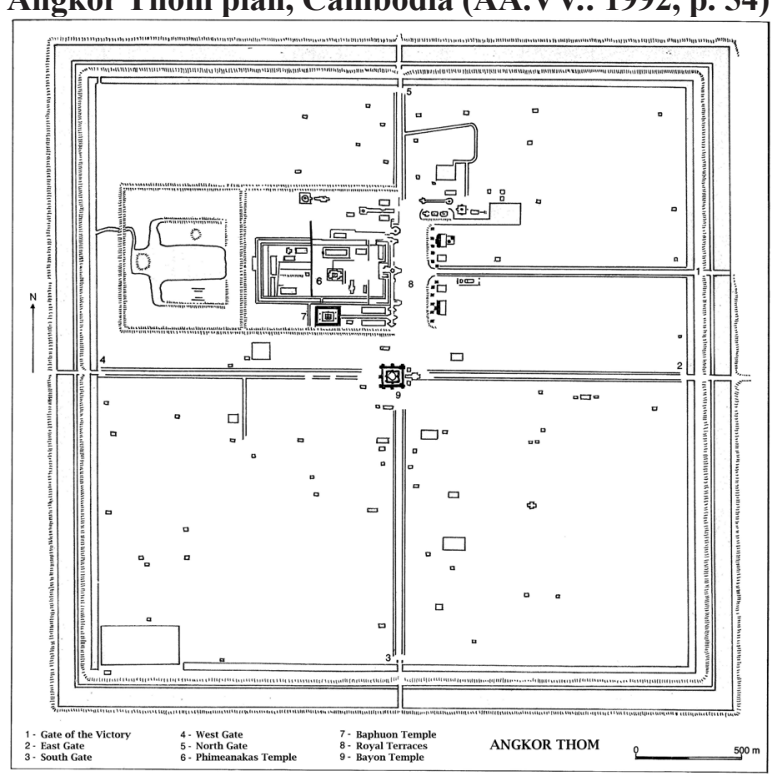

Figure 2

Angkor Thom, main gate (author's photo, 2008)

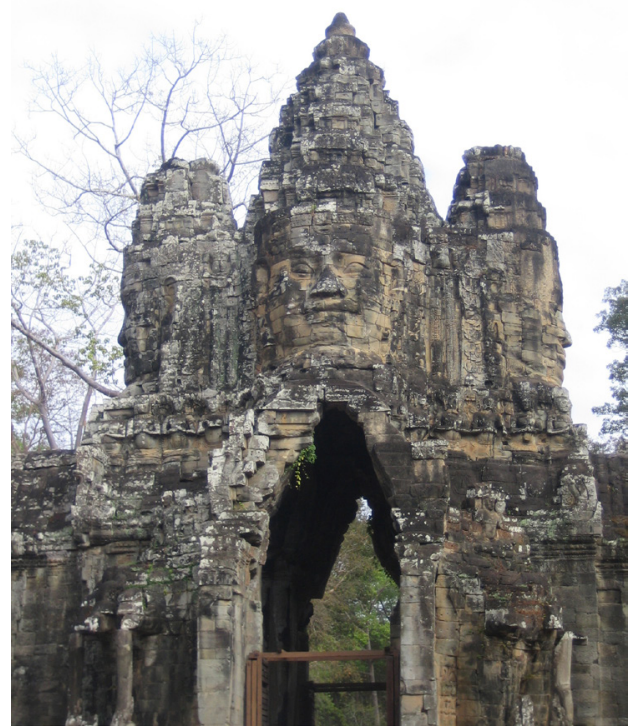

Figure 3

Angkor Thom, city walls (author's photo, 2008)

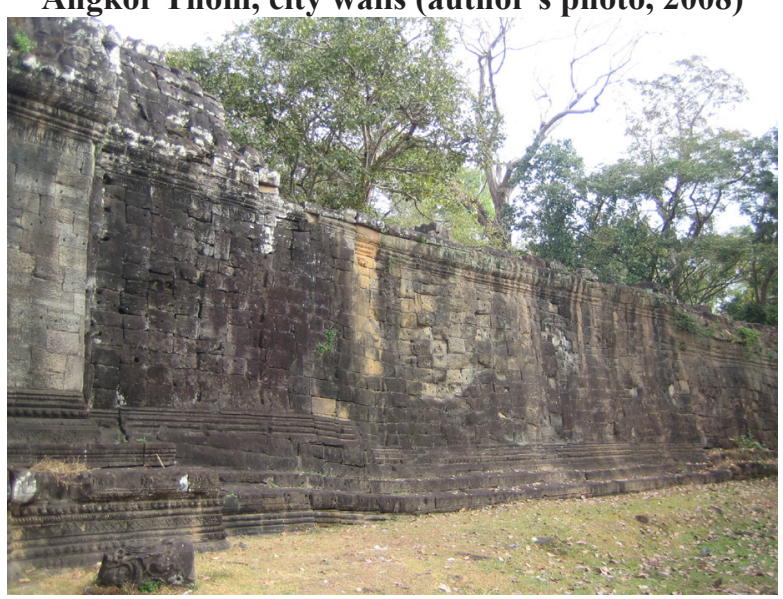

\section{HO CITADEL (VIETNAM)}

This is probably the best example of a stone fortification in the whole Southeast Asia, in relation to its massive and impregnable appearance, its magnificent regular structure as well as its notable conservation status.

It is found in Vinh Loc district, Thanh Hóa province, in the north of Vietnam ${ }^{13}$, about $250 \mathrm{~km}$ from the modern Communist Republic of China. The chosen location was a fertile plain terrain of rice fields comprised between Ma River (West) and Buoi River (East), and Mount Tuong Son (North) and Mount Don Son (South), a place of strategic importance. It was built in 1397, in only three months, by Ho Quy Ly King, founder of the ephemeral Ho dynasty, to house the new capital of the country ${ }^{14}$. In 1407 the Chinese Ming Empire conquered the kingdom of Dai Viet and the seat of the power was again transferred back to Thang Long (ancient Hanoi) ${ }^{15}$. However, the citadel kept its role as a military fortification and remained also as the political, economic and cultural centre of the region from the $16^{\text {th }}$ to the $18^{\text {th }}$ century ${ }^{16}$. Although the stone-faced ramparts of the fortress were partly destroyed during the turbulent period of the Tay Son rebellions (1778-1802), all of its perimeter is well preserved nowadays to a considerable height.

An impressive inner stone wall marked the limits of the royal citadel, the centre of the city. Perfectly designed and firmly constructed, it has a square layout of $877 \mathrm{~m}$ (north and south sides) $\mathrm{x}$ $880 \mathrm{~m}$ (east and west sides), that is $77 \mathrm{ha}$, devoid of towers. There is a great gate at the centre of 
each side: the North, East and West gates had only one single entrance, while the principal one (at the South, measuring $15 \mathrm{~m}$ wide) had three gateways, all of them precisely covered by semicircular arches or barrel vaults composed by wedge-shaped voussoirs, and with the central arch slightly larger than the lateral arches. Only the South and North gates have kept their upper terraces, on the top of which large round holes bear witness to the former existence of wooden pavilions. Those four gates were connected by the main axis of the citadel, two inner roads $(4.85 \mathrm{~m}$ wide) paved with flat stones which crossed in the centre and which have survived until the present time.

Technically, the walls consist of thick earth ramparts faced externally and internally by layers of ashlars, large limestone blocks meticulously shaped and arranged in perfect regular rows. Large size stones which reach the weight of 26.7 tons were placed at foot to consolidate the base and smaller rectangular stones placed on them ${ }^{17}$. It has been estimated that more than 100,000 cubic metres of earth and 20,000 of stone hewn from local quarries were used in its construction. The top of the wall was crowned with brick defensive structures, which are not visible anymore. The gates and the corners of the curtain walls have a slightly tapering form, given its inclination towards the interior.

The walls of the citadel were surrounded on all the sides by moats originally filled with water with an average width of $50 \mathrm{~m}$; although nowadays they are mostly covered by earth, its vestiges are still clearly identifiable in every direction. An outer wall (La Thanh) protected the rest of the buildings and residences of city. With a total perimeter of about $10 \mathrm{~km}$ (enclosing thus a surface of 600-700 ha), it had an irregular layout, adapted to the local topography, the surrounding rivers and hills. For the most part the natural setting was used with defensive purposes, while other parts were reinforced with earth ramparts, ditches and bamboo brushwood fences. The best preserved remains of the rampart can be seen in the fields of Vinh Phuc (to the southeast of the inner citadel) and of Vinh Long (to the northeast), which measure about $4 \mathrm{~km}$ long in total ${ }^{18}$.
Figure 4
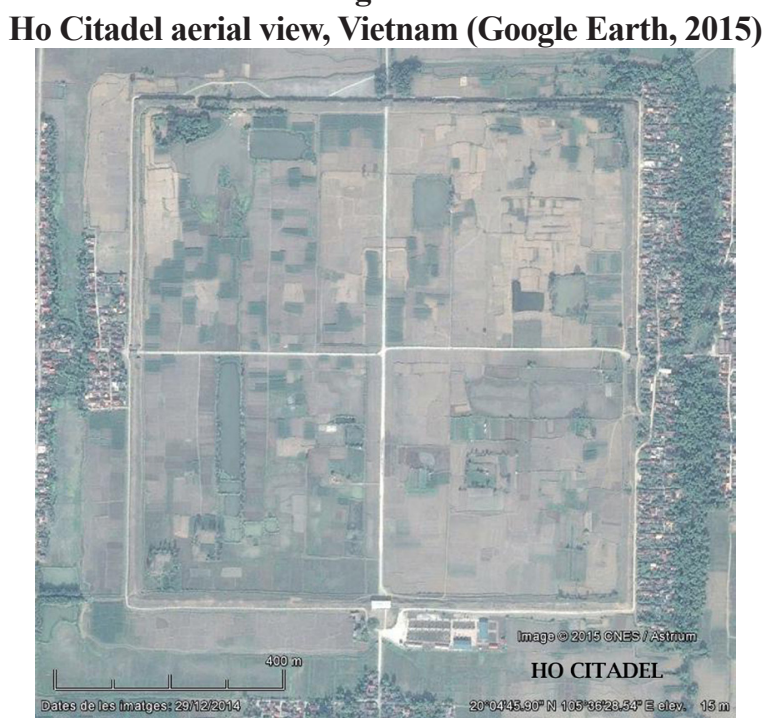

Figure 5

Ho Citadel, city walls (author's photo, 2013)

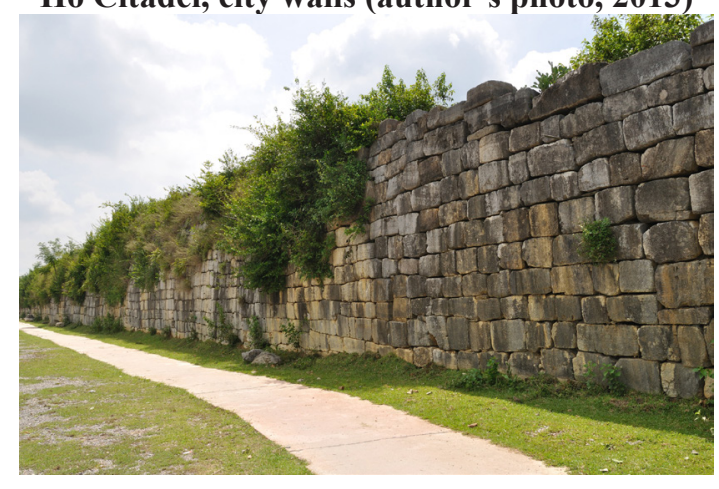

Figure 6

Ho Citadel, main gate (author's photo, 2013)

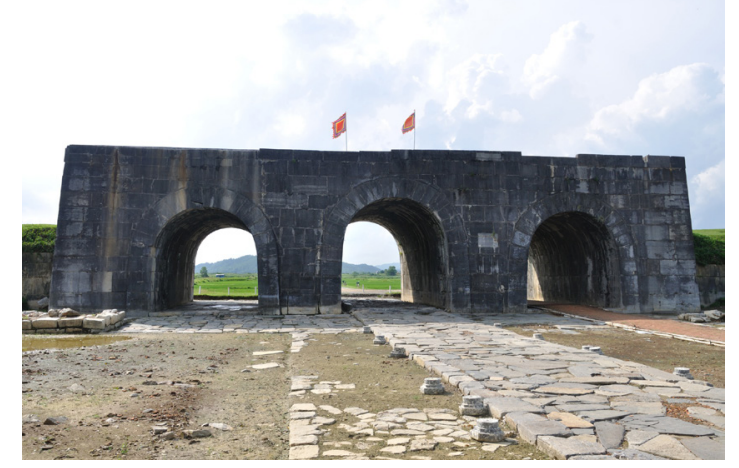

\section{RATU BOKO (INDONESIA)}

This is a unique case of a stone fortification in Southeast Asia. Unlike the city of Angkor Thom and the Ho Citadel, the whole archaeological area of Ratu Boko was perfectly not closed with a sole 
continuous perimetral enceinte, its fortifications don't constitute a structural unity and the walls don't have a so impregnable appearance as those from Angkor and Ho Citadel. Another difference to be highlighted is the location, an easy-todefend hill position with visual control over the surrounding territories, instead of a vulnerable plain which would have required stronger artificial defences. Finally, although its stone walls served for defensive purposes, besides showing power and prestige, some of them also had an additional practical function such as enclosing a building or retaining the soil of terraces.

Kraton Ratu Boko, which in Javanese language means "palace of King Boko"19, was one of the royal residences of ancient Mataram State as well a centre of religious importance, commenced construction in 760-780, in the time of King Panangkaran ${ }^{20}$, later transformed by King Rakai Walaing Pu Kumbhayoni ${ }^{21}$ (856-863) and continued to be inhabited up to the $14^{\text {th }}-15^{\text {th }}$ century. Mataram was a Hindu-Buddhist kingdom $\left(8^{\text {th }}\right.$ and $9^{\text {th }}$ centuries) based in Central and East $\mathrm{Java}^{22}$. The capital was placed by its founder, King Sanjaya, in the former region of Mataram (modern Yogyakarta), which comprised the fertile volcanic plains of Kedu (Borobudur) and Kewu (also known by the name of Prambanan). Ratu Boko was erected on a small plateau of 16 hectares, at the top of a hill of 160-200 meters of altitude above the sea level, about three kilometres to the south of Prambanan Temple, in the major archaeological area of the whole Indonesia ${ }^{23}$.

The monumental site of Ratu Boko is formed by three compounds: one in the north-west, another in the south-east, both of them well known and studied, while the north-eastern one, the smaller, has not been fully excavated yet. Those compounds are formed by successive terraces on different levels, divided by several courtyards bounded by retaining walls or enclosures. Since most of the structures have been built of wood and other organic material, only their stone bases and walls remain nowadays. The site comprises several types of buildings: audience hall (pendopo), princess palace or women's quarter (kaputren), reception pavilion (paseban), royal baths, temples, shrines, crematorium and meditation caves carved into the rock $^{24}$.
Stone-faced ramparts, freestanding stone walls and dry moats (not filled with water) are the fortified elements of the palace complex which, albeit present everywhere, are concentrated mainly in the north-western part of the plateau, facing the sole access path ${ }^{25}$. The second and third terraces are sustained by walls of about $170 \mathrm{~m}$ long $(\mathrm{N}-\mathrm{S})$, the second one slightly higher $(5 \mathrm{~m})$ than the third one $(4 \mathrm{~m})$; between those two walls there is an intermediate fence $(3 \mathrm{~m}$ high) running parallel to them and pierced by the main gate, which appear again in the south side of the third terrace ${ }^{26}$. The E-W retaining wall of the third terrace measures about $130 \mathrm{~m}$. In the base of the second terrace a narrow moat was excavated, while the third terrace has in both of its sides a stone paved flat-bottom ditch or open duct (about $1 \mathrm{~m}$ wide), as well as the remnants of a front wall or fence, today only preserved in its original height $(3 \mathrm{~m})$ in one part, similar to a detached military outwork.

The south-east area has two terraced retaining walls of 150 and $130 \mathrm{~m}$ respectively $(\mathrm{N}-\mathrm{S})$, the second one of them provided with the same kind of ditch and front wall or fence. In that compound can be found the outstanding stone enclosure of a building identified as the Audience Hall (pendopo). It has a rectangular layout of $40.8 \mathrm{~m}(\mathrm{~N}-\mathrm{S}) \times 33.9 \mathrm{~m}$ (E-W), pierced by three simple doors (north, west and south), and the walls, measuring $3.45 \mathrm{~m}$ high, are the finely shaped and crowned with a row of decorative pinnacles. Near there, in a lower terrace, the bathing complex also has a massive rectangular stone enclosure of around $50 \mathrm{~m}(\mathrm{E}-\mathrm{W})$ x $60 \mathrm{~m}(\mathrm{~N}-$ $\mathrm{S})$, with a gate in the middle of each side. In the north-eastern compound, atop the hill, there are remains of an enclosure wall.

Two kinds of stone were used in the construction of the fortifications: the retaining walls of the terraces, the front freestanding walls or outworks and the enclosure of the baths are made of white limestone, a soft sedimentary rock, while the main gateway and the walled enclosure of the Audience Hall were made of andesite, a hard igneous rock. Thus, the best quality material was reserved for the most important structures of the palace site. As for the masonry technique, although in the Audience Hall the stone was cut in rectangular blocks (ashlars) arranged in regular rows, in other places the blocks didn't have a 
so regular a shape nor were arranged in such a perfect position. It is possible to observe with the naked eye the inner composition of the walls of baths: these are formed by two external facings of ashlars and a filling of irregular stones mixed with mortar. By contrast, the outer walls that surround the ditches of the terraces are composed of three layers of ashlars, two externals and one internal. The retaining walls of the terraces have a slope, while the walls of the Audience Hall and the bathing complex as well as the freestanding walls erected in front of the stone-faced ramparts have a vertical position.

The main gate, located at the westernmost past of the site, consists of two successive gateways (gopura), located at two levels in different terraces and connected by stairs: the first gateway has three rectangular doors -that is, covered with straight architraves instead of arches or vaults-, while the second one, bigger, has five doors ${ }^{27}$. This is at the same time the most fortified point of the palace complex and also the most monumental one, due to the double necessity of protecting a week point (access) and also of impressing the visitor with a magnificent architectural design. We can find the remains of inner gates and stairs at the E-W side of the third north terrace, as well as in the N-S side of the south terrace ${ }^{28}$.

\section{Figure 7}

Ratu Boko plan, Indonesia (Degroot: 2010, p. 143)

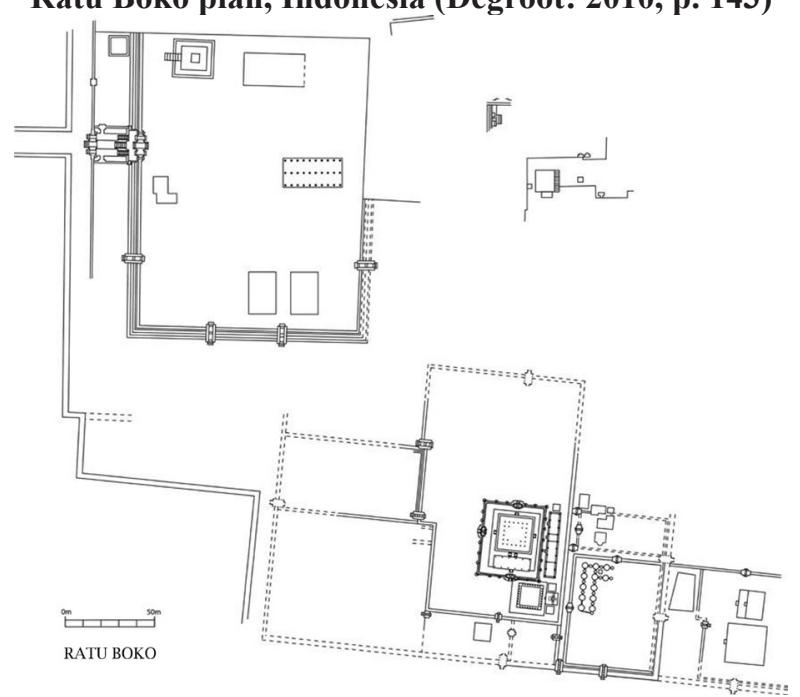

Figure 8

Ratu Boko, embankment (author's photo, 2014)

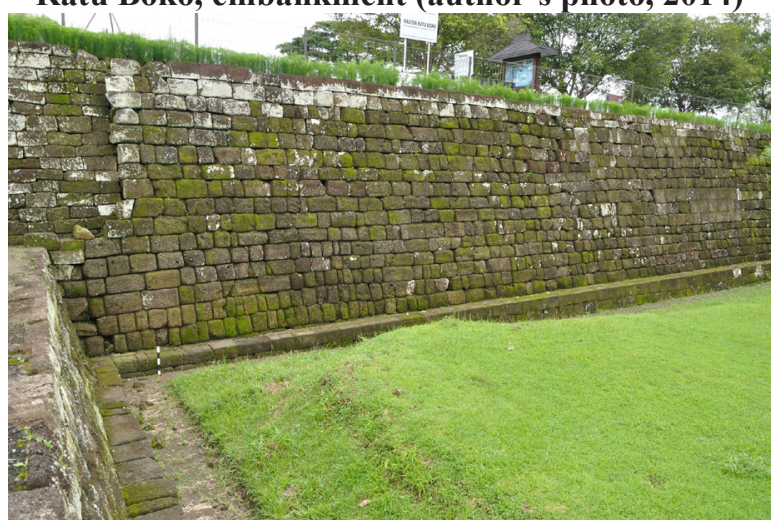

Figure 9

Ratu Boko, main gate (author's photo, 2014)

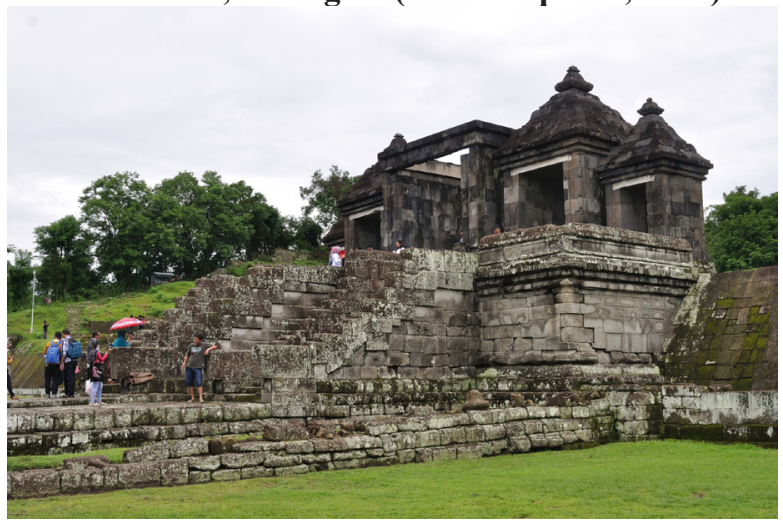

Figure 10

Ratu Boko, audience hall wall (author's photo, 2014)

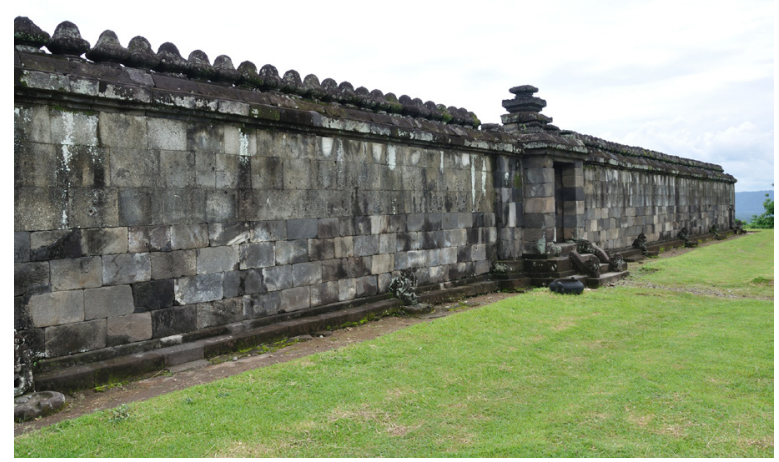

\section{COMPARISONS AND CONCLUSIONS}

Although these three cases might appear to be isolated examples in their regional context, in fact their design, structure and technical characteristics can be closely related to the fortifications of neighbouring empires (China and India), as places 
of origin of their strong cultural influences. On the one hand, Angkor Thom and Ratu Boko, like any other architectural production of the HinduBuddhist states which flourished during the first millennium $\mathrm{AD}$ and the half of the second one in Southeast Asia, have been clearly influenced by the old Indian tradition. On the other hand, the construction of Ho Citadel followed the typical precepts of the millenarian Chinese tradition. In order to better understand this fact, we should keep in mind that the Khmer Empire (Cambodia) as well as the Medang Kingdom (Indonesia), formed part of the Indian cultural sphere or Indosphere ${ }^{29}$, whereas the Dai Viet Kingdom (Vietnam) was integrated into the Chinese cultural sphere or Sinosphere ${ }^{30}$.

Let us examine in the first place the particular case of Ho Citadel. Culturally and historically we should distinguish between the Viet and the Champa territory (in the north and in the south of modern Vietnam), which were respectively influenced by the Chinese and Indian civilizations. It was not until the beginning of the $19^{\text {th }}$ century when the Vietnamese ended to conquer the Cham land. Hence it's not surprising to find the capital of the ephemeral Ho Dynasty in the north, as well as Hanoi, the traditional Viet capital, both of them planned and fortified according to the Chinese principles of geomancy, urbanism and military architecture. Obviously 1400 years of direct political Chinese domination left a strong mark on the country, starting from the design of capital cities with their regular defensive walls.

According to the ancient Chinese texts referring to architecture and urbanism ${ }^{31}$, the ideal city consisted of a square, a theory which may have derived from the belief that the heavens were round and the earth was square. And just as the earth has four cardinal points, also the city should have gates in those directions, connected by main roads which would serve as the central axis for arranging the inner space according to a grid pattern, symbol of order. Although this shape was the preferred norm in the flat plains of northern China, the topographical conditions sometimes determined the adoption of irregular perimeters in the rougher territory of the south ${ }^{32}$. The selection of the site was determined by the search of a favourable geographical position; thus, feng shui recommended to locate cities on level land with a river in the front and a mountain behind. In the capitals, the imperial palace should be placed in a pre-eminent position, which varied from the centre to the north depending on the historical period. The wall symbolized the sovereign's reign on the earth. And the importance of the surrounding enceinte is revealed by the fact that a same word was used in Chinese to design a city and a city wall (cheng) ${ }^{33}$.

We should take now a quick glance at the general characteristics of the Chinese urban fortifications in order to establish some morphological comparisons ${ }^{34}$. The main similarities between them and the defensive system of the Ho Citadel are: quadrangular plan, thick walls of massive appearance, wide moats preceding the curtain wall ${ }^{35}$, presence of a distinctive inner city or citadel and an outer city provided both of them with perimeter wall ${ }^{36}$, and monumental gates in all the cardinal points often covered with barrel vaults and provided with wooden upper structures (gate towers). However, amongst the differences, we can notice at the Ho Citadel the absence of barbicans or defensive courtyards in the gates, the non-existence of projecting square towers arranged at regular distance, archaeologist couldn't find any trace of the typical Chinese "sheep-horse walls" (yang-ma cheng) or low preceding walls (proteichisma) erected between the main walls and the moat, and finally, although the walls are composted by a core of rammed earth the facing is not made of bricks -as was frequent in the whole China- but of stones.

The closest parallel, in the time and space, of a Chinese capital city with ashlars in their fortifications can be found in Nanjing, imperial seat of the Ming Dynasty between the years 1368 and 1421, coinciding with the foundation and Chinese conquest of the Ho Citadel. Nevertheless, the curtain walls of Nanjing ${ }^{37}$ (1368-1389) were not only faced with stone but still with brick as the main material. Moreover, their stone blocks were not all rectangular nor as huge as those from the Ho Citadel.

As for the rest of royal citadels of the Viet kingdom before the $19^{\text {th }}$ century, all of them were protected with brick and/or earth enceintes -making thus the limestone walls of the Ho Citadel more exceptional in its context- and had 
a quadrangular layout. This is even the case of Co Loa Citadel (Hanoi) in the period previous to the first Chinese domination of the country, with a rectangular earthwork and brick citadel $(1.65 \mathrm{~km}$ of perimeter) dated from $3^{\text {rd }}$ century $\mathrm{BC}$ surrounded by two outer irregular ramparts provided with towers $(6.5$ and $8 \mathrm{~km})$ and three moats filled with water from Hong River ${ }^{38}$. The Thang Long Citadel (Hanoi), capital city between the $11^{\text {th }}$ and $18^{\text {th }}$ centuries, was constructed also brick in 1029 on the remains of the previous Chinese fortress dating from the $7^{\text {th }}$ century, with a rectangular perimeter, four gates oriented towards the cardinals points and a Chinese imperial layout; in addition, an inner and an outer irregular enclosures of earth protected the city ${ }^{39}$.

There is another case of stone-like fortification in Vietnam, further to the South. However, in contrast to the Ho Citadel, the rectangular earth and laterite walls $(1400 \times 1100 \mathrm{~m})$ of the Cha Ban or Vijaya citadel (Canh Tien, Binh Dinh), capital of an Indianised Champa kingdom between the $11^{\text {th }}$ century and the Viet invasion in 1471 , reminds the Hindu-Buddhist style of stone or laterite fortifications ${ }^{40}$. Moreover, unlike other Champa centres which used bricks as a primary material of construction, the abundant well-cut stone and laterite blocks from Vijaya reveal a major influence from the neighbouring Khmer Empire, especially from Angkor Thom ${ }^{41}$.

The closest parallel to the city walls of Angkor Thom, regarding to the geographical proximity, shape, design and chronology of the defensive perimeter, can be found in Phimai (ancient Vimayapura, nowadays located in modern Thailand), an important Khmer town. Its urban fortifications draw a rectangle $(1033 \times 665 \mathrm{~m})$ constructed with laterite blocks in the time of King Jayavarman VII (1181-1218), replacing the previous fortifications from the $11^{\text {th }}$ century ${ }^{42}$.

Quadrangular capital cities which followed the principles of Indian urbanism and cosmology were frequent in the Indochinese Peninsula: Sukhothai (Thailand, founded in 1238), with a complex rectangular defensive system $(1800 \mathrm{x}$ $1360 \mathrm{~m}$ ) composed by a wall of bricks and laterite, two embankments and three moats; Chiang Mai (Thailand, fortified in 1336-1355), with a brick city wall and a moat of $1750 \mathrm{~m} \times 1750 \mathrm{~m}$; Amarapura and Mandalay (founded in 1782 and 1857 in Burma, present Myanmar), both of them with a square-shaped brick city wall preceded by a moat (1000 m and $2000 \mathrm{~m}$ per side, respectively $)^{43}$. However, in all these cases -as well as in others not cited here-, brick was the material broadly used, not laterite like in the Khmer cases of Angkor Thom or Phimai.

According to Indian technical treatises on architecture and urbanism (vastu-shastras) compiled in the Antiquity and influential until the arrival of Muslims, a military camp, fort, village or town, either circular or square in plan, should be encircled by ramparts and moats and were supposed to have two major axial roads aligned with the four cardinal points. A capital city not only served as the political centre of the state and the seat of the monarchy, but also it was a representation of the whole Indian universe, like a microcosm. The main temple was a replica in the Earth of the mythological Mount Meru, and the whole city was erected around it. Hence, the main temple was installed at the central crossing of the two axial roads, while the king palace to its north. And within the walls, akin to a sacrificial enclosure, there was a ring road corresponding to the path of the auspiciousness around a sacred site. However, those rules were more theoretical than practical, although Angkor Thom is a perfect example of this conventional foundational plan of a Hindu capital city ${ }^{44}$.

Archaeology reveals that the quadrangular form of city plan was frequently used in Burma, territory which constitutes the entrance gate to the Indochinese Peninsula from India, since the first millennium of the Christian era until the British conquest in the 19th century ${ }^{45}$, a fact that helps to explain the spread of this urban tradition into neighbouring countries like Thailand or Cambodia together with the spread of the Hindu-Buddhist culture and architecture in particular. Nevertheless, it seems that more efforts were made to apply the theoretical principles of the ideal city according to the ancient and medieval Hindu urbanism and cosmology in the South-East Asia, that is in the Indian influenced kingdoms, rather than in the Hindustan Peninsula were they were originated. 
In India the regular designs of the plans which resemble mandalas are found in religious enceintes instead of fortified towns.

A notable exception are the meticulously planned fortifications of the square cities of Jaugada and Kalinganagara in Shishupalgarh (Orissa), dated from $3^{\text {rd }}$ and $2^{\text {nd }}$ centuries $\mathrm{BC}^{46}$. The defences of Jaugada consisted of a wide earthen rampart $(900 \times 1050 \mathrm{~m}, 45 \mathrm{~m}$ wide and 7 $\mathrm{m}$ high) with two protruding gates per side and a moat ${ }^{47}$. The defences of Kalinganagara consisted of a laterite wall facing a rampart oriented along the cardinal directions $(1200 \times 1160 \mathrm{~m}, 4.7 \mathrm{~km}$ of perimeter, $3 \mathrm{~m}$ wide wall, $36 \mathrm{~m}$ wide and $16 \mathrm{~m}$ high rampart), with bastions in the corners, two protruding main gates per side and a moat fed by a nearby stream. In comparison with the gates of Angkor Thom (both of them wide enough to allow the access of chariots or elephants), those of Kalinganagara are more efficient in terms of military defensive technique, thanks to its complex structure provided with barbicans, opened at the top so that invaders could be bombarded with arrows from all directions ${ }^{48}$, while in Angkor Thom decorative giant faces were preferred.

We should take now a rapid glance at the general characteristics of Hindu fortifications in order to establish some morphological comparisons ${ }^{49}$. The main similarities between the strongholds of the Indian subcontinent (during the first millennium and until the $14^{\text {th }}$ century ${ }^{50}$ ) and those from the South-East Asian Indian influenced countries are: solid curtain walls composed of high and thick earthen embankments faced with hard material (stone, laterite or bricks) laid without mortar and preceded by wide and deep moats, and the use of corbel arches or monolithic lintels to cover relatively simple gateways ${ }^{51}$. Several differences can be noted, notwithstanding: prevalence of fortifications in India with and irregular layouts over regular quadrangular plans, preference for high positions for defence (rocky hills whenever possible) over plain terrains, major use of stone blocks over bricks as the priority material of construction, more extensive use of towers and of defensive structures designed to resist a massive military siege or the attack of sophisticated war engines ${ }^{52}$. We can add one more difference: curtain walls tended to be more massive and thicker in India than in Angkor Thom.

As for the last of the three stone walls examined in this article, Ratu Boko, it is a particular case which requires more careful attention given its controversial nature. Indeed, the function of this site had been widely debated by the researchers, both by field archaeologists and analyst scholars, and in some occasions the fortified character of the structures was even put in doubt. Nevertheless, in my opinion, the different stone walls not only had a function of retaining the soil of the terraces in the case of the sloping ramparts, or a symbolic function (prestige, exaltation of power and/or separation from the rest of the world) in the case of the free standing enclosures, but they also had a defensive purpose, no matter if secondary, or at least they can be used to provide protection to the complex in case of external menace. We should keep in mind that, unlike Angkor Thom and the Ho Citadel, which were founded on plain terrain vulnerable to the attack of big armies, the elevated position of Ratu Boko and the presence of escarpments in the hill made the construction of massive impregnable fortification works unnecessary.

On the other hand, it is very probable that the centre evolved from a pre-eminently religious one towards a political one, always maintaining a close link between the secular authority and the state cult, making thus impossible to separate them in the proposed interpretations. Although it seems that Ratu Boko was originally (760-780) designed as a Buddhist monastery promoted by royal patronage, about one hundred years later (856-863) the site was transformed into a royal palace ${ }^{53}$ by a Hindu ruler, devoted to the cult of Shiva.

While some authors considered the site as a royal palace garden ${ }^{54}$, others had underlined mainly the influence of the Sri Lankan Buddhist monastery Abhayagiri Vihara ${ }^{55}$ (Anuradhapura), some centuries older. The comparisons have been established according to these similarities: name, location on a hill, presence of meditation halls or caves for ascetics ${ }^{56}$, and alleged architectural parallels ${ }^{57}$. Anyway, I prefer to highlight these evidences: on the one hand, both sites were constructed thanks to the patronage of local rulers and served both as religious centres and 
royal capitals provided with recreational areas for the kings ${ }^{58}$; on the other hand, Ratu Boko experienced an evolution over the time and had multiple functions, including a fortified residence of the civil authority, which particularly attracts my attention.

Although constructed later, between the $12^{\text {th }}$ and the $13^{\text {th }}$ centuries, I would mention here another parallel of different nature: the imperial palace of Angkor Thom. Similar to Ratu Boko but at higher scale, it also contains a fortified perimeter (moat and rectangular laterite walls of $246 \times 585$ $\mathrm{m})$, monumental gates with multiple entrances (gopura), pools and ponds, religious structures (a temple from the end of the $10^{\text {th }}$ century), royal terraces (stone foundations for pavilions) and a great number of buildings including residences for the king, for his wives and concubines, guards and soldiers, all of them erected with perishable materials which have been long vanished ${ }^{59}$.

Kraton (or keraton) is a type of native Indonesian traditional building which historically had functioned as the residence of a royal family ${ }^{60}$. A fundamental component of a kraton is the pendopo, a quadrangular wooden pavilion structure built on columns, used to shelter the institutions of ancient Javanese kingdoms, such as law courts, clergy, palaces, and for public appearances of the king and his ministers ${ }^{61}$. The elevated platforms, the bases for pillars (umpak), the design of the plan and other archaeological indices reveal clearly the former existence of this kind of pavilions in Ratu Boko. Given the perishability of the organic materials, the remains of the ancient pendopos are often limited to the lower stone or brick elements, like in the case of the original royal pavilions of Trowulan, the $14^{\text {th }}$ century capital city of the Majapahit Empire. The first timber structures preserved from the $15^{\text {th }}$ (kraton Kasepuhan in Cirebon), $16^{\text {th }}$ and $17^{\text {th }}$ centuries suggest that the design of pendopos had not changed much for over a millennia, keeping the same structural elements since the $8^{\text {th }}$ century Ratu Boko remains and the $9^{\text {th }}$ century representations from the Borobudur reliefs ${ }^{62}$.

The moat and the stone walls of the $16^{\text {th }}$ century Kraton Kotagede ${ }^{63}$ (Yogyakarta) remind us that the Javanese palaces were protected by defensive works, the same as the palaces of other neighbouring Indian influenced kingdoms like Angkor Thom; therefore, Ratu Boko is not an exceptional case, but the oldest remains in its category. Actually, all palaces since the Medang Kingdom $\left(8^{\text {th }}-9^{\text {th }}\right.$ c.) were a collection of pendopo style pavilions and halls surrounded by walls. Considering that the Indonesian urban centres did not fully develop until the $13^{\text {th }}$ century ${ }^{64}$, in this period the cities from Java were not walled like those from Europe, Middle East, China or India. Hence, the only well-guarded and protected constructions were the king's palace and temple compound $^{65}$.

As for the most direct influence of the architecture of Ratu Boko, this can be appreciated in nearby constructions from Yogyakarta area just a few decades later, although they are of a purely religious nature. This is the case of the perimeter walls of the Hindu Prambanan temple complex, especially the inner enceinte, and the upper terrace of the much smaller Hindu Barong sanctuary, with sloped retaining walls and a double successive gate (gopura $)^{66}$, both of them dated in the middle of the $9^{\text {th }}$ century. The central courtyard of Prambanan is the best example of large walls built the double facing technique, very popular in that time in Java, similar to free standings enclosure walls of Ratu Boko: perfectly adjusted volcanic stones were used for the façades, while the inner part was made of cheaper materials, crudely hewn limestone blocs and a mixture of lime and mud ${ }^{67}$.

Finally, although the size is not as colossal or impressive as other fortresses from Mainland Southeast Asia, we should remark that the archaeological and historical value of the defences of Ratu Boko is due to the exceptionality of solid non-perishable material in that period for protection purposes (no matter if primary or secondary): as Chinese written sources from the $9^{\text {th }}$ century state when describing the country and its inhabitants, in that time the Javanese people made fortifications of wood $^{68}$. Such an early use of stone in walls, embankments and ditches reveals the important role of the site for the society and political authorities, which deserved to be considered in this study. 


\section{REFERENCES}

AA.VV. (1992). Arqueología de las ciudades perdidas, vol. 28, Extremo Oriente, Salvat, Barcelona.

AA.VV. (2015). Kraton Ratu Boko. A Javanese site of enigmatic beauty, Wisata Candi Borodudur, Prambanan \& Ratu Boko, Jakarta.

Albanese, Marilia (2006). Los tesoros de Angkor, Guías de Arte y Viajes, Libsa, Madrid.

Aymonier, Étienne (1904). Le Cambodge 3. Le groupe d'Angkor et l'histoire, Ernest Leroux, Paris.

Chapman, William (2013). A heritage of ruins. The ancient sites of Southeast Asia and their conservation, University of Hawaii Press, Honolulu.

Coe, Michael D. (2003). Angkor and the Khmer civilization, Thames \& Hudson, London.

Coedès, George (1968): The indianized states of Southeast Asia, University of Hawai Press, Honolulu.

Bernet Kempers, August John (1959). Ancient Indonesian art, Harvard University Press, Cambridge, Massachusetts.

Bernet Kempers, August John (1978). Herstel in Eigen Waarde. Monumentenzorg in Indonesie, Walberg, Amsterdam.

Bezacier, Louis (1952). "Conception du plan des anciennes citadelles capitales du Nord Vietnam"JournaAsiatiquel 40pp.185-195.

Bezacier, Louis (1955). L'Art vietnamien, Éditions de l'Union Française, Paris.

Bezacier, Louis (1972). Manuel d'archéologie d'Extrême-Orient. Tome 2. Le Viêt-Nam, Picard, Paris.

Briggs, Lawrence Palmer (1954). The ancient Khmer empire, Transactions of the American Philosophical Society, 41, Philadelphia.

Bullough, Nigel (1995). Historic East Java. Remains in stone, The East Java Tourism Promotion Foundation, Singapore.

Casparis, J.G. de (1956). Prasasti Indonesia II. Selected inscriptions from the 7th to the 9th century A.D., Masa Barn, Bandung.

Chihara, Daigoro (1996). Hindu-Buddhist Architecture in Southeast Asia, Studies in Asian Art and Archaeology 19, Brill, Leiden.

Christie, Jan Wisseman (1991). "States without cities: Demographic trends in Early Java", Indonesia 52 , pp. 23-40.
Christie, Jan Wisseman (2001). "Revisiting early Mataram", Fruits of inspiration. Studies in honour of Prof. J.G. de Casparis, Egbert Forsten, Groningen, pp. 25-55.

Coningham, Robin \& Manuel, Mark \& Davis, Christopher (2015). "Archaeology and cosmopolitanism in Early Historic and Medieval Sri Lanka", Sri Lanka at the crossroads. From antiquity to modernity, Cambdridge University Press, Cambridge, pp. 1-29.

Degroot, Véronique (2006). "The archaeological remains of Ratu Boko: from Sri Lankan Buddhism to Hinduism", Indonesia and the Malay World, 34, 98, pp. 55-74.

Degroot, Véronique (2010). Candi, space and landscape. A Study on the distribution, orientation and spatial organization of central Javanese temple remains, Sidestone Press, Leiden.

Degroot, Verónique et alii (2013). Magical Prambanan, Taman Wisata Candi Borodudur, Prambanan \& Ratu Boko, Jakarta.

Deloche, Jean (2007). Studies on fortification in India, Collection Indologie 104, École Française d'Extrême-Orient, Paris

DiBiasio, Jame (2013). The story of Angkor, Silkworm Books, Chiang Mai.

Do, Quang Trong \& Nguyen, Xuan Toan \& Le, Thi Lien \& Le, Thi Thu Trang (2011): Ho Citadel. The world heritage, Vol. 1. The outstanding universal values, Social Sciences Publishing House, Hanoi.

Dumarçay, Jacques (1986). The temples of Java, Oxford University Press, Oxford.

Dumarçay, Jacques (1993). L'histoire de l'architecture de Java, École Française d'Etrême-Orient, Paris.

Dumarçay, Jacques (1998). The site of Angkor, Oxford University Press, Oxford.

Dumarçay, Jacques \& Smithies, Michael (1995). Cultural sites of Burma, Thailand and Cambodia, Oxford University Press, OxfordSingapore-New York.

Dumarçay, Jacques \& Royère, Pascal (2001). Cambodian architecture. Eighth to Thirteenth centuries, Brill, Leiden.

Fass, Virginia (1986). The forts of India, Collins, London.

Fontein, Jan \& Soekmono, R. \& Suleiman, Satyawati (1971). Ancient Indonesian art of the Central 
and East Javanese periods, Asia Society, New York.

Freeman, Michael (1998). A guide to Khmer temples in Thailand and Laos, Weatherhill, Boston (Massachusetts).

Gaucher, Jacques (2004). “Angkor Thom, une utopie réalisée? Structuration de l'espace et modèle indien d'urbanisme dans le Cambodge ancien", Arts Asiatiques 59, pp. 58-86.

Giteau, Madeleine (1996). Histoire d'Angkor, Editions Kailash, Paris.

Glaize, Maurice (1993). Les monuments du groupe d'Angkor, Maisonneuve, Paris.

Groeneveldt, W. P. (1876). Notes on the Malay Archipelago and Malacca, compiled trom Chinesesources,Bruning,Batavia(Jakarta).

Hall, K.R. (1985). Maritime trade and state development in early South East Asia, University of Hawaii Press, Honolulu.

Hambali, Halina (1993). Keraton Ratu Boko in Yogyakarta, Directorate General for Culture DepartmentofEducationandCulture,Jakarta.

Higham, Charles (2003). Civilization of Angkor, Phoenix, London.

Hla, U Kan (1978). "Traditional Town Planning in Burma", Journal of the Society of Architectural Historians, vol 37, n 2 (May), pp. 92-104.

Huard, Pierre \& Durand, Maurice (1954). Connaissance du Viet-Nam (Viet-Nam. Civilisation and Culture), École française d'Extrême-Orient, Hanoi.

Ibbitson Jessup, Helen (2004). Art \& Architecture of Cambodia, Thames \& Hudson, London.

Inajati-AA.VV. (2005). "Kota Gede: An archaeological perspective of a capital city in Java in the 17th century", Humaniora 17, no 2 Juni, pp. 125134.

Jacq-Hergoualc'h, Michel (2007). The armies of Angkor. Military structure and weaponry of the Khmers, Orchid Press, Bangkok.

Jacques, Claude \& Freeman, Michael (2008a). Ancient Angkor, Books Guides, River Books, Bangkok.

Jacques, Claude \& Freeman, Michael (2008b). Angkor. Cities and temples, River Books, Bangkok.

Kim, N.C. \& Van Toi, L. \& Hiep, T.H. (2010). "Co Loa. An investigation of Vietnam's ancient capital”, Antiquity 84 (326), pp. 1011-1027.

Krom, N.J. (1923). Inleiding tot de Hindoe-Javaansche Kunst (Introduction to Hindu-Javanese Art), 3 vols, Nijhoff, The Hague.

Kinney, Ann R. (2003). Worshiping Siva \& Buddha. The temple art of east Java, University of Hawaii Press, Honolulu.

Lal, Braj Basi (1949). "Sisupalgarh 1948: An early historical fort in Eastern India", Ancient India 5, pp. 62-105.

Le, Thanh Khoi (1981). Histoire du Viet Nam des origines à 1858, Sudestasie, Paris.

Lombard, Denys (1968). “Jardins à Java”, Arts Asiatiques 9, pp. 135-184.

Lunet de Lajonquière, Étienne Edmond (1902-1911). Inventaire descriptif des monuments $d u$ Cambodge, 3 vols., École Française d'ExtrêmeOrient, Paris.

Marr, David G. \& Milner, Anthony Crothers et alii (1986). Southeast Asia in the 9th to 14th Centuries, Institute of Souteast Asian Studies Research School of Pacific Studies, Singapore - Canberrra.

Mazzeo, D. \& Antonini, C.S. (1978). Monuments of civilization. Ancient Cambodia, Grosset \& Dunlap, New York.

Miksic, J. (1993-1994). "Double Meditation Platforms at Anurâdhapura and the pendopo of Ratu Boko", Saraswati. Esai-esai Arkeologi 10, Kalpataru 2, pp. 23-31.

Millet, Didier \& Miksic, John (2003). Ancient History. Indonesian Heritage Series, vol. 1, Archipelago Press, Singapore.

Mishra, Ratanlal (2002). Military architecture in ancient India, B.R. Publishing Corportation, Delhi.

Mitra, Debala (1957). "Jaugada”, Indian archaeology. A review (1956-7), pp. 30-31.

Motô, Hinago (1986). Japanese Castles, Kodansha International, Tokyo-Nova York-San Francisco.

Munoz, Paul Michel (2006). Early kingdoms of the Indonesian Archipelago and the Malay Peninsula,EditionsDidierMillet,Singapore.

Naerssen, F. H. van (1963). "Some Aspects of the Hindu-Javanese Kraton", The Journal of the Oriental Society of Australia, pp. 14-18.

Needham, Joseph et alii (1994). Science and Civilisation in China, vol. 5, part 6, Military Technology: Missiles and Sieges, Cambridge University Press, Cambridge.

Nguyen, Thi Thuy (2009). Thanh Tay Do va vung dat Vinh Loc (Thanh Hoa) tu cuoi the ky XIV Den 
giua the ky XIX (Tay Do citadel and the land of Vinh Loc -Thanh Hoa- from the end of the XIV to the middle of the XIX centuries), Ph.Doctor thesis, National Library, Hanoi.

Nossov, Konstantin S. (2006). Indian castles 12061526, Osprey Publishing, Oxford.

Park, Seon-Yong et alii (2007). A basic research on mountain fortress in central inland area of Korea, The Korea Fortress Academy, Chungcheongbuk-do Province, Cheongju.

Parmentier, Henri (1909-1918). Inventaire descriptif des monuments cams de l'Annam, 2 vols, École Française d'Extrême-Orient, Paris.

Patra, Benudhar (2007): "Jaugada. An early historical fort town of Orissa", Orissa Review, January 2007, pp. 44-47.

Pérez Garcia,Víctor Lluís (2010). Anàlisi comparativa dels feudalismes japonès i europeu: aspectes militars i fortificacions (Comparative analysis of Japanese and European Feudalism: Military aspects and fortifications), Vision Libros, Madrid.

Phuong, Tran Ky (2012). Vestiges of Champa civilization, The Gioi Publishers, Hanoi.

Schinz, Alfred (1996). The magic square. Cities in ancient China, Edition Axel Menges, StuttgartLondon.

Schweyer, Anne-Valérie (2005). Le Vietnam ancien, Les Belles Lettres, Paris.

Schweyer, Anne-Valérie (2011). Ancient Vietnam. History, art and archaeology, River Books, Bangkok.

Shatzman, Nancy (1999). Chinese imperial city planning, University of Hawaii Press, Honolulu.

Sit, Victor (2010). Chinese city and urbanism. Evolution and development, New Jersey.

Soekmono, R. (1979). "The archaeology of Central Java before 800 AD”, Early South East Asia. Essays in archaeology, history and historical geography (Smith \& Watson eds.), Oxford University Press, New York, pp. 457-472.

Soekmono, R. (1988). Pengantar Sejarah Kebudayaan Indonesia (Introduction to the cultural history of Indonesia), vol. 2, Penerbit Kanisius, Yogyakarta.

Soekmono, R. (1995). The Javanese candi. Function and meaning, Studies in asian art and archaeology 17, Brill, Leiden.
Soetarno, R. (2002). Aneka candi kuno di Indonesia (Ancient Temples in Indonesia), Dahara Prize, Semarang.

Steinhardt, Nancy Shatzman (1999). Chinese imperial city planning, University of Hawaii Press, Honolulu.

Suleiman, Satyawati (1981). Monuments of Ancient Indonesia, Pusat Penelitian Arkeologi Nasional, Jakarta.

Sundberg, Jeffrey Roger (2003). “A Buddhist mantra recovered from the Ratu Baka plateau: a preliminary study of its implications for Sailendra-era Java", Bijdragen tot de Taal-, Land-en Volkenkunde 159, n. 1, pp. 163-188.

Sundberg, Jeffrey Roger (2004). "The wilderness monks of the Abhayagirivihara and the origins of Sino-Javanese esoteric Buddhism", Bijdragen tot de Taal-, Land- en Volkenkunde 160, n. 1, pp. 95-123.

Tjahjono, Gunawan \& Miksic, John (2003). Architecture Indonesian Heritage Series, vol. 6, Archipelago Press, Singapore.

Toy, Sidney (1957). The strongholds of India, London.

Turnbull, Stephen (2003). Japanese Castles 1540-1640, Osprey Publishing, Oxford.

Turnbull, Stephen (2007). The Great Wall of China 221BC-AD 1644, OspreyPublishing, Oxford.

Turnbull, Stephen (2008). Japanese Castles AD 2501540, Osprey Publishing, Oxford

Turnbull, Stephen (2009). Chinese walled cities 221 $B C$ - $A D$ 1644, Osprey Publishing, Oxford.

Ung, Mai \& Hung, Dao (1993). Hue. Monuments of an ancient capital, The Gioi Publishers, Hanoi.

Van der Meulen, W.J. (1979). "King Sanjaya and his successors", Indonesia 28, pp. 17-54.

Vann Molyvann, S. E. (1999). Les cités khmer anciennes, Toyota Foundation, Phnom Penh.

Wijesurya, G.S. (1998). Buddhist Meditation Monasteries of Ancient Sri Lanka, Department of Archaeology, Colombo.

Yin, Yang et alii (2005). The eternal Great Wall, China National Art Photograph Publishing House, Beijing.

Yule, Paul \& Böhler, Wolfgang (2004). "Sisupalgarh: An early historic fortress in coastal Orissa and its cousins", Beiträge zur allgemeinen und vergleichenden Archäologie 24, pp. 15-29.

Yule, Paul (2006). Early historic sites in Orissa, Pragun Publications, Delhi. 


\section{ENDNOTES}

1 The working methodology consisted of visual surveys and in situ analysis, making a high resolution detailed photo archive, visiting specialized museums and interpretation centres of the fortifications, besides an exhaustive bibliographic and planimetric research.

2 Yin et alii: 2005; Turnbull: 2007 \& 2009.

3 Motô: 1986; Turnbull: 2003 \& 2008; Pérez: 2010.

4 Park: 2007.

5 Toy: 1957; Fass: 1986; Mishra: 2002; Nossov: 2006; Deloche: 2007.

6 Briggs: 1954; Giteau: 1996; Higham: 2003; Coe: 2003; DiBiasio: 2013.

7 The name of Angkor Thom, which literally means "Great City" in Khmer language, was in use from the $16^{\text {th }}$ century. Originally, the successive capitals installed in the zone were called Yasodharapura, "Holy City", "Glory-bearing City" or, by extension, "Capital City", in Sanskrit.

8 More modest calculations estimate a population inside the walls of around 200,000 inhabitants. In any case, in the $12^{\text {th }}$ and $13^{\text {th }}$ centuries Angkor Thom was not only the biggest town in Southeast Asia, but also one of the most populated cities in the world, together with Hangzhou and Kaifeng (China), Constantinople (Byzantine Greece), Córdoba (Muslim Spain), Bagdad (Iraq) and Merv (Turkmenistan).

9 Besides to the obvious secondary function of imperial and urban prestige, together with its symbolism linked to Indian cosmology, an inscription found in the site confirms that the walls were primarily built for defensive purposes.

10 Aymonier: 1904, pp. 87-141; Glaize: 1993; Dumarçay: 1998; Albanese: 2006; Jacques \& Freeman: 2008a \& 2008b.

11 Local people traditionally called them "Gate of the Dead" (East), "Gate of the Victory" (North-East), "Gate of paddling lake" (South), "Gate of Ta Kao" (West) and "Gate of Ta Nok" (North).

12 Laterite is a type of highly compacted and cemented clay soil rich in iron oxides and aluminium, formed in hot and humid tropical areas, which it hardens into solid rock in contact with the air and becomes resistant to atmospheric conditions, being therefore suitable as a construction material easy to cut into brick-shaped blocks. The chemical formation process named laterization consists of an intensive and long-lasting weathering or leaching of the underlying parent rock (About the use of lemonite laterite in the architecture of the Khmer Empire: Aymonier: 1904; Lunet de Lajonquière: 1902-1911;
Mazzeo \& Antonini: 1978; Dumarçay \& Smithies: 1995; Dumarçay \& Royère: 2001).

13 Archaeological descriptions of the Ho Citadel in: Parmentier: 1909-1918; Huard \& Durand: 1954; Bezacier: 1955 \& 1972; Schweyer: 2005 \& 2011.

14 The new royal citadel was named Tay Do ("West Capital"), while the former royal residence of Thang Long was recalled Dong Do ("East Capital").

15 Bezacier: 1952, pp. 185-195; Ung \& Hung: 1993.

16 Le: 1981.

17 The average dimensions of the ashlars are $2.2 \times 1.5$ x $1.2 \mathrm{~m}$. The bigger stone blocks measure $4.2 \times 1.7$ $\mathrm{x} 1.4 \mathrm{~m}$ and $5.1 \times 1 \times 1.2 \mathrm{~m}$.

18 Nguyen: 2009; Do \& Nguyen \& Le \& Le: 2011.

19 Kraton or keraton (royal palace) is a modern Javanese word derived from ka-ratu-an which literarily means "the residence of ratu". Ratu is the traditional honorific title to refer the ruler (king or queen). In ancient Javanese language kraton was called kadatwan (Christie: 1991, p. 29).

20 Sundberg: 2003, pp. 163-188.

21 Casparis: 1956.

22 Coedès: 1968, pp. 87-93, 125-130; Van der Meulen: 1979, pp. 17-54; Christie: 2001, pp. 25-55; Millet \& Miksic: 2003.

23 Bernet: 1959; Fontein \& Soekmono \& Suleiman: 1971; Dumarçay: 1986; Chapman:2013,pp. 35-58.

24 Theoretical proposal of functional identification based on typological similarities with architectonic parallels (other Javanese keraton and the royal palace of Angkor Thom) which we will examine at the end of this article. Moreover, this is the hypothesis which follows the local tradition related to the site.

25 Some sides of the complex (especially at the north) didn't need any retaining wall, since they are naturally limited by steep slopes of the hill and cliffs.

26 This western area is known by locals as Mount Tlatar, which in Javanese language means "hill of arranged stones".

27 The first gate measures 12.15 x 6.9 x 5.05 m (length, width and high), whereas the second gate measures 18.6 X 9 X $4.5 \mathrm{~m}$.

28 Krom: 1923; Soekmono: 1979, pp. 457-472, 1995; Dumarçay: 1993; Hambali: 1993; Soetarno: 2002; Degroot: 2010; AA.VV.: 2015.

29 India, Pakistan, Bangladesh, Nepal, Tibet, Burma, Thailand, Cambodia, Laos, Champa (Southern Vietnam), Indonesia, Malaysia and Brunei.

30 China, Korea, Japan and the Viet land (Northern Vietnam).

31 Steinhardt: 1999, pp. 29-36.

32 It seems that the flat terrains of the basins of Hong or Red River (Hanoi) and Ma River (Ho Citadel) 
favoured the adoption of the ideal Chinese square fortified city plan in the North of Vietnam. In some cities from the south of China with irregular outer walls (like Nanjing), the royal citadel or inner "imperial city" kept a quadrangular fortified layout, same as we find at Ho Citadel.

33 Schinz: 1996; Shatzman: 1999; Sit: 2010.

34 Needham et alii: 1994; Turnbull: 2009.

35 Although in the North of China dry moats were dug in order to avoid water became frozen in winter, in the South of China as Well as in the Indonchinese peninsula wet moats were usually part of flowing rivers.

36 The fortified citadel contained the imperial palace, administrative offices, as well as barracks of military forces.

37 Schinz: 1996, pp. 300-305; Shatzman: 1999, pp. 161-166; Sit: 2010, pp. 203-205.

38 Kim \& Van Toi \& Hiep: 2010, pp. 1011-1027.

39 Schweyer: 2011, pp. 252-279.

40 Parmentier: 1909-1918; Phuong: 2012, pp. 75-79.

41 And, as other capitals of the ancient kingdoms in Southeast Asia, within the city walls of Cha Ban were the residences of the king, his family and officials and priests while the rest of the people lived outside of the enclosure.

42 Freeman: 1998; Vann Molyvann: 1999.

43 Chihara: 1996.

44 Gaucher: 2004, pp. 58-86.

45 Hla: 1978, pp. 92-104.

46 Lal: 1949, pp. 65-105; Mitra: 1957, pp. 30-31.

47 Patra: 2007, pp. 44-47; Yule \& Böhler: 2004, pp. 16-19; Yule: 2006.

48 Yule \& Böhler: 2004, pp. 15-29; Yule: 2006.

49 Deloche: 2007.

50 Although some improvements where introduced in India to the art of building strongholds between the $11^{\text {th }}$ and $14^{\text {th }}$ centuries (like the construction of successive earthworks, bulkier towers and more complex gateways), the major modifications in military architecture appeared towards the end of the $15^{\text {th }}$ century, as a result of the introduction of gunpowder and firearms.

51 Hindu-Buddhist architecture traditionally didn't use the genuine arch or vault with voussoirs. Those two structures were a contribution of the Muslims, introduced during the rule of the Delhi Sultanate (1206-1525) in the north of India and during the Mughal occupation ( $16^{\text {th }}$ and $17^{\text {th }}$ centuries $)$ in the rest of the Peninsula (Nossov: 2006).

52 Jacq-Hergoualc'h: 2007.

53 Ancient stone inscriptions revealed that the site changed its name from "Abhayagiri Vihara" (or "peaceful Buddhist monastery"), in the $8^{\text {th }}$ century, to "Walaing Kraton" (or "palace of King Walaing"), in the $9^{\text {th }}$ century. The archaeology confirmed the modification or implementation of the uses, as well as the adding of Hindu shrines close to the Buddhist religious buildings (Degroot: 2006, pp. 55-74). "Kraton Ratu Boko" was the name given after the place was abandoned by the local people (from Dawangsari village) who believed it was founded by the legendary Javanese King Boko.

54 Bernet: 1978, p. 23.

55 Wijesuriya (1998) and Coningham \& Manuel \& Davis (2015, pp. 1-29) described the doubleplatform monasteries (padhanaghara parivena) from Sri Lanka, mainly Anuradhapura and Ritigala. 56 Miksic: 1993-1994, pp. 23-31.

57 According to Degroot (2006, pp. 55-74), the whole south-eastern compound of Ratu Boko appears to have been conceived as a replica of Anurâdhapura, an opinion I think is not that clear. Conversely, I see more similarities with other walled Javanese palaces (kraton) and royal audience halls (pendopo) build in subsequent centuries. Sundberg (2004, pp. 95-123) also discussed this controversial topic and pointed not only the similarities but also the differences between Ratu Boko and the monasteries of Sri Lanka.

58 As Lombard had analysed (1969, pp. 135-183), the royal gardens in Java combined facilities for bathing, religious activities including meditation in caves, and high walls which would have been useful as fortifications, although they were not primarily meant for that purpose.

59 Aymonier: 1904, pp. 87-142; Ibbitson: 2004, pp. 113-117; Jacques \& Freeman: 2008a, pp. 106-113.

60 Naerssen: 1963, pp. 14-18.

61 Pendopos have wide eaves and a pyramidal or hipped roof standing on a square or rectangular terrace, and they consist of an open hall that have no external or partitioning walls and they are supported only by rows of pillars (Chihara: 1996, p. 215).

62 Suleiman: 1981; Bullough: 1995; Kinney: 2003; Tjahjono \& Miksic: 2003.

63 The 6.5 ha palace was protected by a $1.2 \mathrm{~m}$ thick wall made of bricks and small limestone blocks, pilled orderly in regular rows without using mortar, and by a moat of 1-3 m deep and 20-30 m wide. Besides this fortified citadel, the city was provided with a 200 ha outer defensive quadrangle, composed by a brick and stone wall and also by a water moat of 15-25 m wide connected to the Gajhwong and Manggisan rivers. Actually, Kota Gede means "large city wall” (Inajati - AA.VV.: 2005, pp. 125-134). 
64 Christie: 1991, pp. 23-40.

65 Coedès: 1968; Hall: 1985; Marr \& Milner: 1986; Soekmono: 1988; Munoz: 2006.

66 Degroot: 2010 (pp. 141-142), 2013 (pp. 144-145).
67 Degroot: 2013, p. 55.

68 Information recorded in the Xin Tangshu (New History of the Tang) by the Chinese ambassadors sent to Java in 860 and 873 (Groeneveldt: 1876, p. $13)$. 